\title{
Childhood polyarteritis nodosa presenting as stroke and arterial hypertension
}

\author{
Mariana Rodrigues, ${ }^{1,2}$ Diana Amaral, ${ }^{2,3}$ João Luís Barreira, ${ }_{1}^{2,3}$ Iva Brito ${ }^{1,2}$
}

${ }^{1}$ Paediatric Rheumatology Unit, Paediatrics Department, Centro Hospitalar de São João, Porto, Portugal

${ }^{2}$ Faculdade de Medicina da Universidade do Porto, Porto, Portugal

${ }^{3}$ Department of Paediatrics, Centro Hospitalar São João, Porto, Portugal

\section{Correspondence to} Dr Mariana Rodrigues, mariana.j.rodrigues@gmail.com

Accepted 12 October 2014
CrossMark

\section{To cite: Rodrigues $M_{\text {, }}$} Amaral D, Barreira JL, et al. BMJ Case Rep Published online: [please include Day Month Year] doi:10.1136/ bcr-2014-207866

\section{DESCRIPTION}

A 6-year-old boy with frequent episodes of fever, myalgia and arthralgia, presented with arterial hypertension (HTN).

When he was 2 years old he was extensively investigated due to a small thalamic stroke, but no diagnosis was made.

While being evaluated for HTN, he presented with a medullar ischaemic stroke. Antinuclear and antineutrophil cytoplasmic antibodies were negative; there was no kidney failure, urinalysis changes or skin lesions. In the presence of recurrent fevers, ischaemic strokes and HTN, we suspected the presence of a vasculitis. A renal arteriography (figures 1 and 2) confirmed the diagnosis of childhood polyarteritis nodosa (cPAN), showing several microaneurysms and irregular constrictions in medium-sized and small-sized renal arteries.

The patient was treated with corticosteroids, ramipril, hypocoagulation and monthly intravenous cyclophosphamide followed by azathioprine, and is currently asymptomatic, without significant deficits.
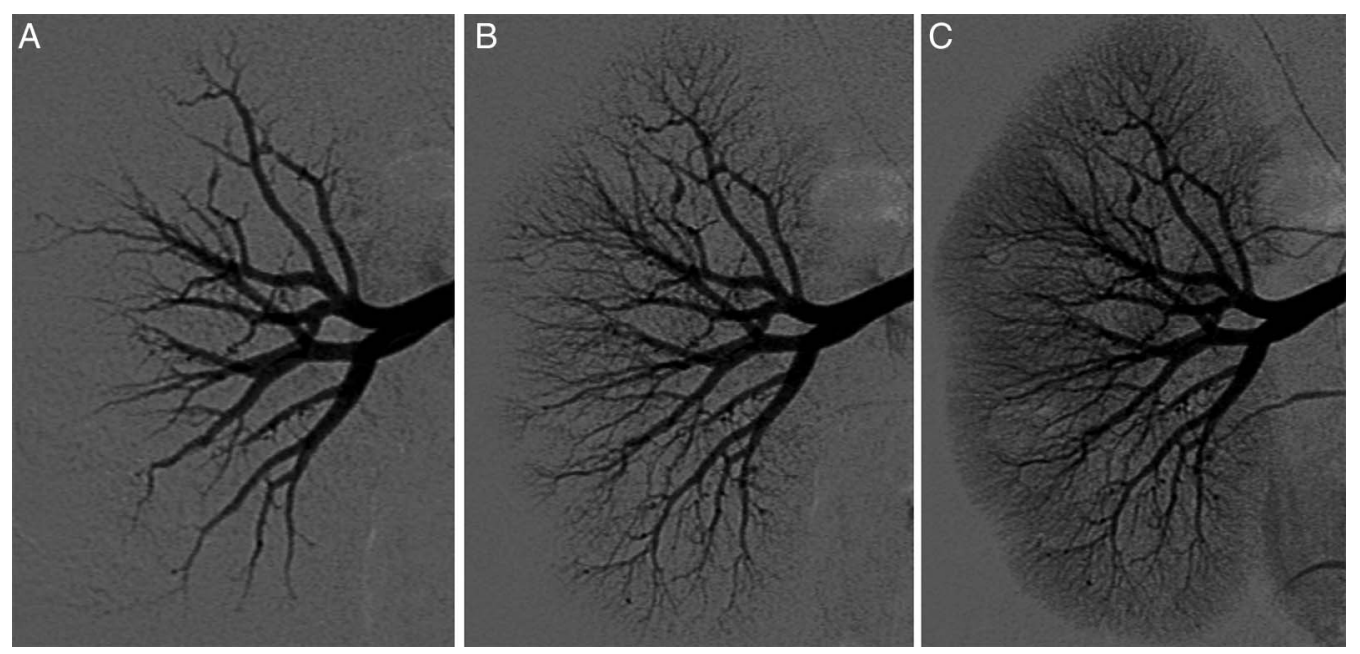

Figure 1 Right selective renal arteriography $((\mathrm{A}-\mathrm{C})$ from early to late phase, respectively) showing several microaneurysms, segmental narrowing and variations in the calibre of arteries in medium-sized and small-sized renal arteries.
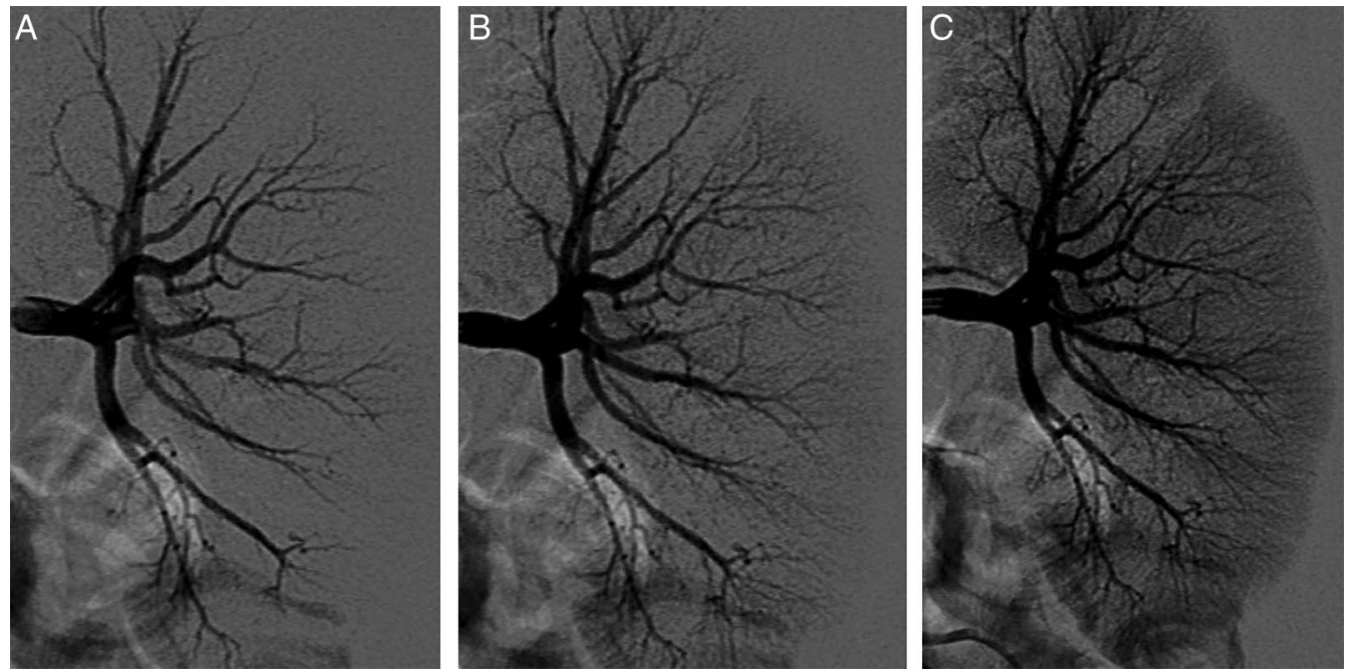

Figure 2 Left selective renal arteriography ( $(\mathrm{A}-\mathrm{C})$ from early to late phase, respectively) showing several microaneurysms, segmental narrowing and variations in the calibre of arteries in medium-sized and small-sized renal arteries. 
According to the EULAR/PReS classification criteria, ${ }^{1}$ the diagnosis of cPAN requires the mandatory presence of necrotising small-sized or medium-sized artery vasculitis or typical angiographical findings.

Several options are available for demonstrating renal involvement in $\mathrm{CPAN}^{2}{ }^{2}$ including less invasive techniques. MR angiography usually fails to detect microaneurysms and overestimates

\section{Learning points}

- In addition to systemic symptoms, the presence of multiorgan involvement should heighten suspicion of vasculitis.

- Vasculitis can present as ischaemic stroke at a young age.

- Renal angiography is useful to confirm the diagnosis in patients with suspected childhood polyarteritis nodosa, particularly if the symptoms and laboratory abnormalities do not direct the choice of biopsy in other territories. stenotic lesions. ${ }^{3}$ CT angiography performs similarly, at the expense of high ionising radiation exposure. ${ }^{3}$

Although biopsy is considered as gold standard for some territories, renal biopsy may fail to detect the pathognomonic changes due to sampling error. ${ }^{2}{ }^{3}$ Also, the presence of small aneurysms increases the risk of bleeding or fistulae formation. ${ }^{2}{ }^{3}$ Therefore, in cases such as this we advocate performing renal biopsy only in patients in whom the arteriography is negative.

Competing interests None.

Patient consent Obtained.

Provenance and peer review Not commissioned; externally peer reviewed.

\section{REFERENCES}

1 Ozen S, Pistorio A, Iusan SM, et al.; Paediatric Rheumatology International Trials Organisation (PRINTO). EULAR/PRINTO/PRES criteria for Henoch-Schönlein purpura, childhood polyarteritis nodosa, childhood Wegener granulomatosis and childhood Takayasu arteritis: Ankara 2008. Part II: Final classification criteria. Ann Rheum Dis 2010;69:798-806.

2 Brogan PA, Davies R, Gordon I, et al. Renal angiography in children with polyarteritis nodosa. Pediatr Nephrol 2002;17:277-83.

3 Amezcua-Guerra LM, Pineda C. Imaging studies in the diagnosis and management of vasculitis. Curr Rheumatol Rep 2007:9:320-7.

Copyright 2014 BMJ Publishing Group. All rights reserved. For permission to reuse any of this content visit http://group.bmj.com/group/rights-licensing/permissions.

BMJ Case Report Fellows may re-use this article for personal use and teaching without any further permission.

Become a Fellow of BMJ Case Reports today and you can:

- Submit as many cases as you like

- Enjoy fast sympathetic peer review and rapid publication of accepted articles

- Access all the published articles

- Re-use any of the published material for personal use and teaching without further permission

For information on Institutional Fellowships contact consortiasales@bmjgroup.com

Visit casereports.bmj.com for more articles like this and to become a Fellow 